\title{
Novel C2orf71 mutations account for 1\% of cases in a large French arRP cohort
}

\begin{tabular}{|r|l|}
\hline Journal: & Human Mutation \\
\hline Manuscript ID: & humu-2010-0434.R1 \\
\hline Wiley - Manuscript type: & Mutation in Brief \\
\hline Dutho Submitted by the & 09-Dec-2010 \\
\hline Complete List of Authors: & $\begin{array}{l}\text { Audo, Isabelle; INSERM, U968, Department of Genetics } \\
\text { Lancelot, Marie-Elise; INSERM, U968, Department of Genetics } \\
\text { Mohand-Saïd, Saddek; INSERM, U968, Department of Genetics } \\
\text { Antonio, Aline; INSERM, U968, Department of Genetics } \\
\text { Germain, Aurore; INSERM, U968, Department of Genetics } \\
\text { Sahel, Jose-Alain; INSERM, U968, Department of Genetics } \\
\text { Bhattacharya, Shomi; CABIMER, Celular Therapy and Regenerative } \\
\text { Medicine } \\
\text { Zeitz, Christina; INSERM, U968, Department of Genetics }\end{array}$ \\
\hline Key Words: & $\begin{array}{l}\text { Rod-cone dystrophies, Retinitis pigmentosa, C2ORF71, genetic } \\
\text { prevalence }\end{array}$ \\
\hline & $\quad$ SCHOLARONE \\
\hline & ManUSCriptS
\end{tabular}


1

2

3

4

5

6

7

8

9

10

11

12

13

14

15

16

17

18

19

20

21

22

23

24

25

26

27

28

29

30

31

32

33

34

35

36

37

38

39

40

41

42

43

44

45

46

47

48

49

50

51

52

53

54

55

56

57

58

59

60
HUMAN MUTATION Mutation in Brief \#__ (20XX) Online

HUMAN MUTATION

\begin{abstract}
Received <date>; accepted revised manuscript <date $>$.
\end{abstract}
(C) 2010 WILEY-LISS, INC.

John Wiley \& Sons, Inc. 


\section{Novel C2orf71 mutations account for $\sim 1 \%$ of cases in a large French arRP cohort}

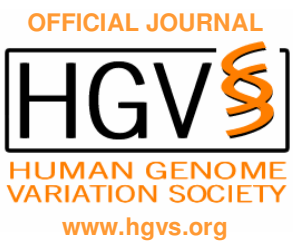

Isabelle Audo 1,2,3,4, Marie-Elise Lancelot1 ${ }^{1,2,3}$, Saddek Mohand-Saïd1,2,3,4, Aline Antonio ${ }^{1,2,3,4}$, Aurore Germain ${ }^{1,2,3}$, José-Alain Sahel1,2,3,4,5,6, Shomi S Bhattacharya ${ }^{1,2,3,5,7}$, and Christina Zeitz'1,2,3

1INSERM, U968, Paris, F-75012, France; ${ }^{2}$ CNRS, UMR_7210, Paris, F-75012, France; 3 UPMC Univ Paris 06, UMR_S 968, Department of Genetics, Institut de la Vision, Paris, F-75012, France; ${ }^{4}$ Centre Hospitalier National d'Ophtalmologie des Quinze-Vingts, INSERM-DHOS CIC 503, Paris, F-75012, France; 5 Department of Molecular Genetics, Institute of Ophthalmology, London, UK; 6 Fondation Ophtalmologique Adolphe de Rothschild, Paris, France; 'Unidad Clínica de Genética, Reproducción y Medicina Fetal. Hospital Universitario Virgen del Rocío, Seville, Spain, Centro de Investigación Biomédica en Red de Enfermedades Raras (CIBERER), Seville, Spain.

${ }^{*}$ Correspondence to Isabellea Audo and Christina Zeitz INSERM, UMR_S968; CNRS, UMR_7210, UPMC Univ Paris 06, Department of Genetics, Institut de la Vision, 17 Rue Moreau, F-75010 Paris, France; Tel.: +33 1534625 40, Fax: +33 153 4626 02; E-mail: isabelle.audo@ inserm.fr, christina.zeitz@ inserm.fr.

Contract grant sponsor: Agence Nationale de la Recherche, Foundation Voir et Entendre, Foundation Fighting Blindness (FFB); Grant number: CD-CL-0808-0466- and C-CMM-0907-0428-(FFB), Ville de Paris et Région lle de France.

Short Title: C2orf71 Mutations in a French cohort.

Communicated by <Please don't enter>

ABSTRACT: Autosomal-recessive retinitis pigmentosa (arRP) is a genetically heterogeneous group of disorders to which a novel gene, $C 2$ orf 71 , was recently associated. The purpose of our study was to establish the prevalence and nature of C2orf71 mutations in a clinically well-characterized cohort of 345 sporadic and arRP French cases. Direct sequencing of C2orf71 was performed in 209 subjects for whom mutations had previously been excluded by microarray technology and direct sequencing of EYS. Putative pathogenicity of the identified variants was evaluated through cosegregation analysis, screening of more than 188 control chromosomes and prediction programs. We identified two patients compound heterozygous for mutations predicted to lead to a premature stop codon, 3 of which are novel. In addition, 3 patients carried a single variant of likely pathogenicity. Furthermore a large number of novel putative non-disease causing variants were identified, highlighting the extremely polymorphic nature of $C 2$ orf 71 . To our knowledge, our study provides the first large scale screening of C2orf71 in a French arRP cohort through direct sequencing and suggests that it would account for approximately 1\% of arRP cases. (C2010 WileyLiss, Inc.

KEY WORDS: Rod-cone dystrophies, RP, C2orf71.

Received <date>; accepted revised manuscript $<$ date $>$.

(C) 2010 WILEY-LISS, INC. 
Rod-cone dystrophy also known as retinitis pigmentosa (RP) is a heterogeneous group of inherited disorders in most cases primarily affecting rods with secondary cone degeneration. It is the most common inherited form of potentially severe retinal degeneration and blindness, with a frequency of about 1 in 4000 births and more than 1 million individuals affected worldwide (Hartong et al. 2006). Patients initially complain of night blindness due to rod dysfunction followed by progressive visual field constriction, abnormal color vision and eventually loss of central vision. Inheritance of RP can be either autosomal recessive (ar), autosomal dominant (ad) or X-linked (xl) with also rare cases of mitochondrial transmission. Recessive and isolated cases account for 50-60\% of all forms of RP (Hartong et al. 2006). So far, 32 genes have been implicated in arRP and 3 additional loci have been mapped (http://www.sph.uth.tmc.edu/Retnet). Most of the identified genes accounted for only 1-2\% of cases each, besides EYS (MIM\# 612424) and USH2A (MIM\# 608400), which were found to account for up to $15.9 \%$ and up to $23 \%$ of isolated arRP respectively (Abd El-Aziz et al. 2008; Audo et al.; Bandah-Rozenfeld et al.; Barragan et al.; Littink et al. 2010) and (Rivolta et al. 2000; Bernal et al. 2003; McGee et al. 2010). Recently, the prevalence of loss-of-function mutations in FAM161A (MIM\#613596) was found to be $12 \%$ in arRP patients from Israel and Palestinian territories (Bandah-Rozenfeld et al. 2010b). However, in a similar study the prevalence of FAM161Amutations in arRP patients from Germany was 2\%-3\% (Langmann et al. 2010). Future prevalence studies will show if FAM161A can be also considered as a major gene in other arRP populations.

Two articles in the same issue of the American Journal of Human Genetics report findings on a new causative gene, C2orf71 (MIM\#613425), for arRP using a homozygosity mapping approach on consanguineous and nonconsanguineous families (Collin et al. 2010; Nishimura et al. 2010). C2orf71 (Chromosome 2 Open reading Frame 71) harbors 2 exons and encodes for a 1288 amino-acid protein. This protein is highly expressed in retina (Collin et al. 2010; Nishimura et al. 2010) and seems to play a role in primary cilia of the outer segment (Nishimura et al. 2010), although its precise function remains to be elucidated. Bioinformatic analysis predicts a proline-rich motif at the C-terminus and functional studies suggest post-translational lipid modifications at the second and third amino acid that may be important for the sorting and function of the protein (Nishimura et al. 2010).

To assess the prevalence of C2orf71 pathogenicity, we screened 209 patients of different ethnic origins from a French cohort of 345 arRP who had previously been excluded for known pathogenic variants by applying a commercially available microarray (ASPER Ophthalmics, Tartu, Estonia) and by direct sequencing of EYS (Audo et al. 2010).

\section{PATIENTS AND METHODS}

Three hundred forty five index patients with a presumed diagnosis of simplex or arRP were ascertained. Informed consent was obtained from each patient and unaffected family member after explanation of the study and its potential outcome. The study protocol adhered to the tenets of the Declaration of Helsinki and was approved by the local ethics committee. Each patient underwent full ophthalmic examination as described earlier (Audo et al. 2010). Total genomic DNA was extracted from peripheral blood leukocytes according to manufacturer recommendation (Puregen Kit, Qiagen, Courtaboeuf, France). Prior to C2orf71 mutation screening, the DNA of all index patients was analyzed for known arRP mutations by microarray analysis on a commercially available microarray (ASPER Ophthalmics, Tartu, Estonia). Samples, which were excluded for known variants were further excluded for mutations in the coding exons and flanking intronic regions of EYS by direct sequencing (Audo et al. 2010). The remaining 209 samples were further investigated for variants in the coding exons and flanking intronic regions of $C 2$ orf 71 by PCR and direct sequencing. The 2 coding exons, and flanking intronic regions of $C 2$ orf 71 were PCR amplified in 11 fragments (C2orf71 RefSeq NM_001029883.1) using oligonucleotides reported in Supplementary Table 1, a commercially available polymerase (HotFire, Solis Biodyne, Tartu, Estonia), 2 mM $\mathrm{MgCl} 2$ at an annealing temperature of $60^{\circ} \mathrm{C}$ for 1 minute. PCR products were enzymatically purified (ExoSAP-IT, USB Corporation, Cleveland, Ohio, USA purchased from GE Healthcare, Orsay, France) sequenced and investigated as previously reported (Audo et al. 2010). Nucleotide numbering reflects cDNA numbering with +1 corresponding to the A of the ATG translation initiation codon in the reference sequence, according to journal guidelines (www.hgvs.org/mutnomen). The initiation codon is codon 1. The correct nomenclature for each change was checked applying Mutalyzer (http://www.lovd.nl/mutalyzer/). PolyPhen (Polymorphism Phenotyping, http://genetics.bwh.harvard.edu/pph/; http://genetics.bwh.harvard.edu/pph2/) (Ramensky et al. 2002; Adzhubei et al. 2010), and SIFT (Sorting Intolerant From Tolerant; http://blocks.fhcrc.org/sift/SIFT.html) (Ng and Henikoff 
2001) software packages as well as evolutionary conservation were used to predict the pathogenic character of the sequence alteration.

A sequence variant was considered to be pathogenic if it represented a nonsense or frameshift mutation and cosegregated with the phenotype. A sequence variant was considered to be of likely pathogenicity if it affects an evolutionary conserved residue on amino acid and nucleotide level, if it was predicted by one or more programs mentioned above to be pathogenic, appeared only 1-3 times in 209 patients and did not show up in at least 188 control alleles. Variants assumed to be most likely non pathogenic did not affect conserved amino acids or nucleotides, represent silent mutations, did not co-segregate with the phenotype, were predicted by both programs to be benign, appeared in $>3$ patients or showed up in controls.

\section{RESULTS AND DISCUSSION}

Mutation screening of C2orf71 by direct sequencing of all coding exons was performed on 209 index patients with a diagnosis of arRP. Of these, 2 patients were compound heterozygous for mutations, which are predicted to lead to premature stop codons (Table 1, first part, Figure 1). Patient CIC00261 from family 180 (II-1 in Figure 1A) was heterozygous for a deletion (c.946delA) (reviewed but not shown) resulting in a frameshift mutation p.Asn316MetfsX7. This would lead to a truncation of more than $80 \%$ of the C2orf71 protein. Co-segregation analysis revealed that this change was inherited from the unaffected mother (I-2, Figure 1A). The same deletion has been reported by Collin et al. as a homozygous mutation in a Dutch family (Collin et al. 2010). Our patient's family originated from the Southwest of France but the mother did not precisely know her ancestral history so a Dutch descent with a founder effect could not be excluded. In addition, CIC00261 was heterozygous for a novel nonsense mutation (c.3002G>A transition), which is predicted to lead to a stop codon (p.Trp1001X) (reviewed but not shown). Co-segregation analysis revealed that this change was inherited from the unaffected father (I-1). The unaffected brother (II-3) showed two normal alleles (Figure 1A). Patient CIC02622 from family 927 (II-3 in Figure 1B) was heterozygous for a novel nonsense mutation (c.2950C >T) leading to a stop codon (p.Arg984X) (reviewed but not shown), which was inherited from the unaffected father (I-1, Figure 1B). In addition, the patient was heterozygous for a novel duplication (c.2327dupC), which is predicted to lead to a frameshift and premature truncation of the protein (p.Leu777PhefsX34) (reviewed but not shown). This change was inherited from the unaffected mother (I-2, Figure 1B). Similar to the index patient, the affected brother (II-5, Figure 1B), was heterozygous for both mutations while the unaffected brother (II-1, Figure 1B) carried only the nonsense mutation.

Table 1: C2orf71 variants which are pathogenic and likely pathogenic 
A
B

c.3002G>A, p.Tr1001X c.946delA, p.Asn316MetfsX7

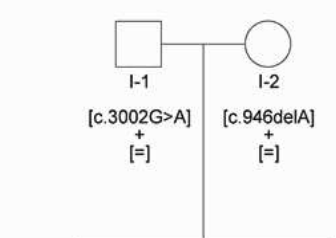

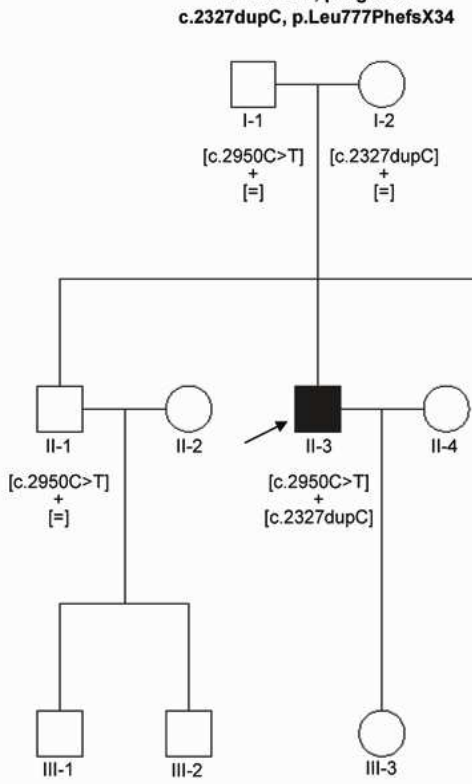

Figure 1: C2orf71 mutations and cosegregation in 2 families with arRP. Filled symbols represent affected and unfilled unaffected subjects. Squares indicate males and circles females. Arrows reflect the index patients. The equal signs depict the normal allele.

Clinical data of index patients for the 2 families are summarized in table 2 and colour fundus and autofluorescence images are displayed in figure 2. Besides a variable age of onset and degree of visual impairment, both patients showed severe retinal dysfunction with marked macular atrophy. Similar clinical findings were reported by Collin and colleagues (Collin et al. 2010). C2orf71 mutations are therefore associated with severe RP and early cone involvement, which highlights the importance of this gene for normal photoreceptor function.

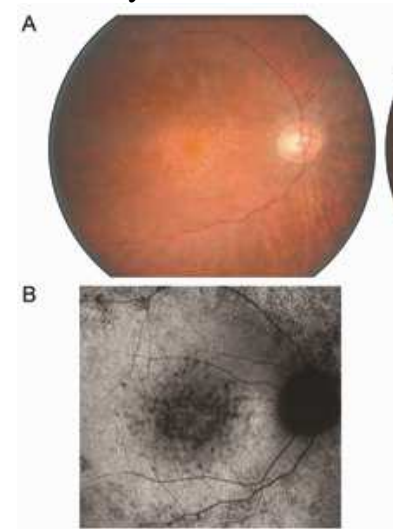

C

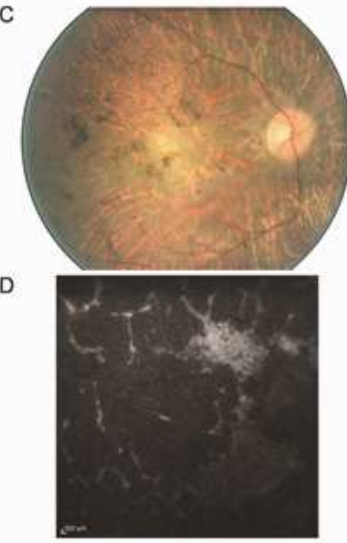

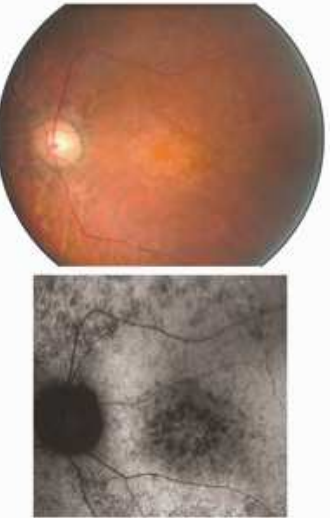

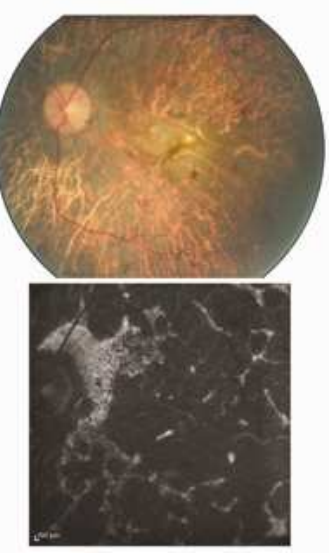

Figure 2: Colour fundus photographs (A-C) and autofluorescence imaging (B-D) of two index patients with C2orf71 muations leading to a premature stop codon. (AB) CIC00261 showed little pigmentation in retinal periphery, some optic disc pallor and narrowed retinal vessels. In addition, there were macular atrophic changes which manifests by a patchy loss of autofluorescence; (CD) CIC02622 showed marked atrophic changes in the posterior pole with large corresponding areas of loss of autofluorescence. 
HUMAN MUTATION Mutation in Brief \#__ (20XX) Online

\section{MUTATION IN BRIEF}

HUMAN MUtation

Table 2: clinical data for the 2 patients compound heterozygous for mutations leading to premature stop codons

\begin{tabular}{|c|c|c|c|c|c|c|c|c|c|c|c|c|c|}
\hline Patient & $\begin{array}{c}\text { Age at } \\
\text { time of } \\
\text { diagnosis }\end{array}$ & $\begin{array}{c}\text { Age at time } \\
\text { of } \\
\text { examination }\end{array}$ & Sex & $\begin{array}{c}\text { Relevant } \\
\text { medical } \\
\text { and } \\
\text { ophthalmic } \\
\text { history }\end{array}$ & $\begin{array}{l}\text { Family } \\
\text { history }\end{array}$ & Symptoms & $\begin{array}{c}\text { BCVA } \\
\text { OD/OS } \\
\text { Refraction }\end{array}$ & $\begin{array}{l}\text { Colour } \\
\text { vision }\end{array}$ & $\begin{array}{l}\text { Binocular } \\
\text { Goldman } \\
\text { visual } \\
\text { field, III4 } \\
\text { isopter }\end{array}$ & $\begin{array}{l}\text { Full } \\
\text { field } \\
\text { ERG }\end{array}$ & $\begin{array}{c}\text { Multifocal } \\
\text { ERG }\end{array}$ & $\begin{array}{c}\text { Fundus and } \\
\text { autofluorescence } \\
\text { imaging } \\
\text { (Figure 2) }\end{array}$ & $\begin{array}{c}\text { Horizontal } \\
\text { foveal } \\
\text { thickness } \\
\text { measured } \\
\text { by SD- } \\
\text { OCT* } \\
\end{array}$ \\
\hline $\begin{array}{l}\text { CIC00261 } \\
\text { Family } \\
180 \\
\text { (II-1) }\end{array}$ & 18 & 35 & $\mathrm{~F}$ & $\begin{array}{c}\text { Refractive } \\
\text { surgery for } \\
\text { myopia at } \\
25\end{array}$ & $\begin{array}{l}\text { None } \\
\text { from } \\
\text { Southwest } \\
\text { of France }\end{array}$ & $\begin{array}{c}\text { Night } \\
\text { blindness } \\
\text { at } 18 ; \\
\text { visual field } \\
\text { constriction } \\
\text { and } \\
\text { decreased } \\
\text { vision at } \\
\text { age } 25\end{array}$ & $\begin{array}{c}20 / 40 \\
20 / 50 \\
+0(-1) 0^{\circ} \\
+0(-1.50) 170^{\circ}\end{array}$ & $\begin{array}{l}\text { tritanopia } \\
\text { at the } 28 \\
\text { Hue of } \\
\text { Roth }\end{array}$ & $\begin{array}{c}40^{\circ} \text { both } \\
\text { horizontally } \\
\text { and } \\
\text { vertically }\end{array}$ & UD & UD & $\begin{array}{c}\text { Typical RP } \\
\text { fundus changes } \\
\text { with little } \\
\text { pigment } \\
\text { migration and } \\
\text { some macular } \\
\text { atrophic changes }\end{array}$ & $\begin{array}{l}\text { OD } 204 \mu \mathrm{m} \\
\text { OS } 181 \mu \mathrm{m}\end{array}$ \\
\hline $\begin{array}{l}\text { CIC02622 } \\
\text { Family } \\
927 \\
\text { (II-3) }\end{array}$ & $\begin{array}{c}\text { Early } \\
\text { childhood }\end{array}$ & 44 & M & none & $\begin{array}{c}\text { One } \\
\text { brother } \\
\text { with RP } \\
\text { from the } \\
\text { West part } \\
\text { of France }\end{array}$ & $\begin{array}{l}\text { Life long } \\
\text { night } \\
\text { blindness } \\
\text { and } \\
\text { decreased } \\
\text { vision }\end{array}$ & $\begin{array}{l}\text { LP both eyes } \\
-3.50(-1) 180^{\circ} \\
-3.25\end{array}$ & NP & $\begin{array}{c}\text { Inferior to } \\
10^{\circ}\end{array}$ & UD & $\begin{array}{c}\text { NP } \\
\text { (unstable } \\
\text { fixation) }\end{array}$ & $\begin{array}{c}\text { Typical RP } \\
\text { fundus changes } \\
\text { with marked } \\
\text { macular atrophic } \\
\text { changes }\end{array}$ & $\begin{array}{l}\text { OD } 147 \mu \mathrm{m} \\
\text { OS } 139 \mu \mathrm{m}\end{array}$ \\
\hline
\end{tabular}

BCVA: best corrected visual acuity; OD: Oculis dextra (right eye); OS: Oculis Sinistra (left eye); UD: undetectable; NP: not performed; LP: light perception;

RP: retinitis pigmentosa; SD-OCT: spectral-domain Optical Coherence Tomography; *normal value 227.64 $\pm 11.74 \mu \mathrm{m}$ (Carpineto et al. 2010). 
C2orf71 screening of our cohort led to the identification of many other variants apart from these 4 premature stop mutations. These changes were classified as of likely pathogenicity (Table 1, second part), most likely non pathogenic (Table 3) and as known variants (Supplementary Table 2).

The group of variants with likely pathogenicity includes 3 missense mutations (Table 1 second part), which were evolutionary conserved (Supplementary Figure 1) and predicted by at least one program to be pathogenic. Unfortunately, no other affected family member of the respective index patients was available for genetic testing to prove the pathogenic character of those mutations. Patients carrying these mutations were only heterozygous for a single mutation. The p.Val615Asp variant was also detected in a patient in a different study investigating C2orf 71 variations in patients with Leber Congenital Amaurosis and arRP (Sergouniotis et al. 2010). As described here no second mutation was identified, but the mutation did not show up in control samples. To date, the 5'UTR of C2orf71 is not described. In addition other isoforms of C2orf71 may exist, which may harbor the second missing mutation. Since our screening strategy was based on direct sequencing of currently known coding exons and flanking regions, we may have missed a second change. This may also hold true for a number of isolated variants identified by Sergouniotis and co-workers (Sergouniotis et al. 2010). In addition, patients may have large heterozygous deletions, which can not be detected by our direct sequencing approach. Another possibility would be that these 3 variants are not pathogenic, that they represent rare variants or that the patients are only carriers. Our screening together with those by Sergouniotis and co-workers (Sergouniotis et al. 2010) showed indeed the highly polymorphic nature of C2orf71, which is concluded from the following results. Pursuing our stringent criteria, we identified 24 non-likely pathogenic variants, of which some were also identified by others (Collin et al. 2010; Sergouniotis et al. 2010). They comprise 15 missense changes, 8 silent mutations and 1 duplication and represent either frequent or very rare variants (Table 3). In addition, many patients were found to only carry one or more known SNPs (Supplementary Table 2). We conclude that all of them were not pathogenic since they appeared frequently in patients or controls in our study or in those performed by Sergouniotis and co-workers (Sergouniotis et al. 2010) or did not affect a conserved amino acid or nucleotide as it is the case for p.His122His Val247Ala and p.Pro1254Leu (data not shown).

All together, our study provides a large scale screening of $C 2$ orf 71 in a French cohort of arRP patients through direct sequencing. It identifies 2 families with 3 novel and 1 known mutations leading to premature stop codon and the absence of protein production as a putative disease mechanism. Furthermore, our study identifies 3 patients heterozygous for variants with uncertain pathogenic character. C2orf 71 would therefore account for at least 0.6$1.7 \%$ of arRP. This figure derives from PCR based exonic sequencing of 209 patients from a total of 345 ar and simplex RP patients. All 345 patients had been pre-screened by microarray or direct sequencing approaches for other RP causing mutations/genes. This pre-screening showed at least a single heterozygous putative mutation in other RP causing genes in 136 patients. Some of them carried two mutations and some of the mutations even showed familial segregation. Of note is that some of the heterozygous mutations amongst the 136 patients may have occurred by chance and therefore it is possible that some of these patients may actually carry a putative C2orf71 mutation. If this were to be true then our estimated figure for C2orf 71 mutation (0.6-1.7\%) is likely to go up since the figure is based on a total of 345 patients and not only on the 209 patients who have been sequenced in C2orf71.

Received <date>; accepted revised manuscript $<$ date $>$.

(C) 2010 WILEY-LISS, INC. 
Table 3: C2orf7l variants that are most likely non pathogenic

\begin{tabular}{|c|c|c|c|c|c|c|c|c|}
\hline Exon & $\begin{array}{l}\text { Sequence } \\
\text { variation }\end{array}$ & Consequence & $\begin{array}{c}\text { Frequency in patient } \\
\text { chromosomes }\end{array}$ & $\begin{array}{l}\text { Frequency in } \\
\text { control } \\
\text { chromosomes }\end{array}$ & $\begin{array}{c}\text { Polyphen } \\
\text { Prediction }\end{array}$ & $\begin{array}{c}\text { SIFT } \\
\text { Prediction }\end{array}$ & Conservation & Co-segregation \\
\hline$\overline{1}$ & c. $679 \mathrm{G}>\mathrm{A}$ & p.Glu227Lys & $\begin{array}{r}5 / 418 \\
\mathrm{~b}_{3 / 572}\end{array}$ & $\begin{array}{r}0 / 190 \\
{ }^{b} 0 / 382\end{array}$ & benign & $\begin{array}{l}\text { affects protein } \\
\text { function }\end{array}$ & conserved & $\begin{array}{c}\text { did not co-segregate in } \\
\text { one family }\end{array}$ \\
\hline 1 & c. $773 \mathrm{G}>\mathrm{T}$ & p.Arg258Ile & $1 / 418$ & $0 / 190$ & $\begin{array}{l}\text { possibly } \\
\text { damaging }\end{array}$ & tolerated & $\begin{array}{c}\text { same nucleotide } \\
\text { found in Stickleback }\end{array}$ & n.d. \\
\hline 1 & c. $935 \mathrm{G}>\mathrm{A}$ & p.Ser312Asn & $1 / 418$ & $0 / 188$ & benign & tolerated & $\begin{array}{c}\text { not conserved on } \\
\text { nucleotide level }\end{array}$ & n.d. \\
\hline 1 & c. $958 \mathrm{C}>\mathrm{T}$ & p.Arg320Cys & $1 / 418$ & $0 / 188$ & benign & tolerated & $\begin{array}{l}\text { same amino acid } \\
\text { found in rat and } \\
\text { mouse }\end{array}$ & n.d. \\
\hline 1 & c. $1132 \mathrm{G}>\mathrm{A}$ & p.Glu378Lys & $1 / 418$ & $0 / 188$ & benign & tolerated & $\begin{array}{c}\text { not conserved on } \\
\text { nucleotide level }\end{array}$ & n.d. \\
\hline 1 & c. $1545 A>G$ & p.Gln515Gln & $1 / 418$ & n.d. & n.a. & n.a. & $\begin{array}{c}\text { not conserved on } \\
\text { nucleotide level }\end{array}$ & n.d. \\
\hline 1 & c. $1882 \mathrm{G}>\mathrm{A}$ & p.Ala628Thr & $2 / 418$ & $0 / 192$ & benign & tolerated & $\begin{array}{l}\text { not conserved on } \\
\text { nucleotide level }\end{array}$ & n.d. \\
\hline 1 & c. $2063 \mathrm{G}>\mathrm{A}$ & p.Cys688Tyr & $\begin{array}{c}4 / 418 \\
\mathrm{~b} 0 / 572\end{array}$ & $\begin{array}{c}5 / 192 \\
\mathrm{~b}_{3} / 190\end{array}$ & $\begin{array}{l}\text { probably } \\
\text { damaging }\end{array}$ & tolerated & not conserved & n.d. \\
\hline 1 & c. $2502 \mathrm{~T}>\mathrm{C}$ & p.Pro834Pro & $\begin{array}{c}2 / 418 \\
\mathrm{~b}_{1} 1 / 572\end{array}$ & $\begin{array}{l}\text { n.d. } \\
\text { b } 0 / 382\end{array}$ & n.a. & n.a. & not conserved & n.d. \\
\hline 1 & c. $2600 \mathrm{C}>\mathrm{T}$ & p.Pro867Leu & $\begin{array}{l}1 / 418 \text { patient } \\
\text { homozygous for this } \\
\text { variant } \\
{ }^{\mathrm{a}} 1 \\
{ }^{\mathrm{b}} 2 / 572\end{array}$ & $\begin{array}{l}\text { n.d. } \\
{ }^{\mathrm{a}} 1 / 180 \\
\mathrm{~b} 1 / 380\end{array}$ & benign & tolerated & not conserved & n.d. \\
\hline 1 & c. $2860 \mathrm{C}>\mathrm{T}$ & p.Pro954Ser & $1 / 418$ & $0 / 190$ & $\begin{array}{l}\text { possibly } \\
\text { damaging }\end{array}$ & tolerated & $\begin{array}{c}\text { not conserved on } \\
\text { nucleotide level }\end{array}$ & n.d. \\
\hline 1 & c. $2864 \mathrm{G}>\mathrm{A}$ & p.Arg955Gln & $\begin{array}{l}3 / 418 \\
\mathrm{~b}_{0} 0 / 572\end{array}$ & $\begin{array}{c}2 / 190 \\
\mathrm{~b} 1 / 190\end{array}$ & benign & tolerated & not conserved & n.d. \\
\hline
\end{tabular}

Received <date>; accepted revised manuscript $<$ date $>$. 


\begin{tabular}{|c|c|c|c|c|c|c|c|c|}
\hline 1 & c. $2875 \mathrm{G}>\mathrm{A}$ & p.Ala959Thr & $\begin{array}{l}2 / 418 \\
1 / 572\end{array}$ & $\begin{array}{l}0 / 190 \\
\text { b } 2 / 190\end{array}$ & benign & tolerated & $\begin{array}{c}\text { not conserved on } \\
\text { nucleotide level }\end{array}$ & n.d. \\
\hline 1 & c. $2889 \mathrm{C}>\mathrm{T}$ & p.Ser963Ser & $\begin{array}{c}6 / 418 \\
b_{3 / 572}\end{array}$ & $\begin{array}{l}2 / 190 \\
\text { b } 2 / 190\end{array}$ & n.a. & n.a. & not conserved & n.d. \\
\hline 1 & $\begin{array}{c}\text { c.3058_3059delCA } \\
\text { insAG }\end{array}$ & p.Gln1020Arg & $\begin{array}{c}6 / 418 \\
b \quad 3 / 572\end{array}$ & $\begin{array}{c}3 / 190 \\
\text { b } 2 / 372\end{array}$ & benign & tolerated & $\begin{array}{c}\text { conservation not } \\
\text { known }\end{array}$ & n.d. \\
\hline 1 & c. $3478 \mathrm{G}>\mathrm{A}$ & p.Ala1160Thr & $1 / 418$ & $0 / 190$ & benign & tolerated & $\begin{array}{c}\text { conservation not } \\
\text { known }\end{array}$ & n.d. \\
\hline 1 & c. $3530 \mathrm{G}>\mathrm{A}$ & p.Arg1177Gln & $2 / 418$ & $0 / 190$ & benign & tolerated & $\begin{array}{l}\text { conservation not } \\
\text { known }\end{array}$ & $\begin{array}{l}\text { did not co-segregate } \\
\text { with the disease in one } \\
\text { family }\end{array}$ \\
\hline 1 & c. $3291 \mathrm{G}>\mathrm{A}$ & p.Gln1097Gln & $\begin{array}{c}6 / 418 \\
b_{3 / 572}\end{array}$ & $\begin{array}{c}5 / 190 \\
\text { b } 1 / 372\end{array}$ & n.a. & n.a. & not conserved & n.d. \\
\hline 1 & c. $3447 \mathrm{G}>\mathrm{A}$ & p.Pro1149Pro & $\begin{array}{l}1 / 418 \\
\mathrm{~b}_{5} / 572\end{array}$ & $\begin{array}{c}1 / 190 \\
\mathrm{~b} 1 / 174\end{array}$ & n.a. & n.a. & not conserved & n.d. \\
\hline 1 & c. $3522 \mathrm{C}>\mathrm{T}$ & p.Asp1174Asp & $\begin{array}{c}1 / 418 \\
\mathrm{~b}_{2} / 572\end{array}$ & $\begin{array}{c}1 / 190 \\
\text { b } 1 / 174\end{array}$ & n.a. & n.a. & not conserved & n.d. \\
\hline 2 & c. $3739 \mathrm{G}>\mathrm{A}$ & p.Gly1247Ser & $\begin{array}{c}4 / 418 \\
\mathrm{~b}_{4} 4 / 572\end{array}$ & $\begin{array}{c}2 / 192 \\
\mathrm{~b} 3 / 300\end{array}$ & benign & tolerated & $\begin{array}{l}\text { conservation not } \\
\text { known }\end{array}$ & n.d. \\
\hline 2 & c.3672_3674dup ${ }^{\circ}$ & p.Ser1225dup & $\begin{array}{c}105 \text { patients } \\
\text { heterozygous, } 23 \\
\text { patients } \\
\text { homozygous/418 }\end{array}$ & $7 / 192$ & n.a. & n.a. & $\begin{array}{l}\text { conservation not } \\
\text { known }\end{array}$ & n.d. \\
\hline 2 & c. $3840 \mathrm{G}>\mathrm{A}$ & p.Ala1280Ala & $\begin{array}{c}1 / 418 \\
\mathrm{~b}_{2} / 572\end{array}$ & $\begin{array}{c}0 / 192 \\
\mathrm{~b} 0 / 300\end{array}$ & n.a. & n.a. & not conserved & n.d. \\
\hline 2 & c. $3789 \mathrm{G}>\mathrm{A}$ & p.Leu1263Leu & $\begin{array}{r}1 / 418 \\
\mathrm{~b}^{\mathrm{b}} 4 / 572\end{array}$ & $\begin{array}{l}0 / 192 \\
{ }^{b} 1 / 300\end{array}$ & n.a. & n.a. & $\begin{array}{c}\text { conserved on } \\
\text { nucleotide level }\end{array}$ & n.d. \\
\hline
\end{tabular}

$\S$ except where it is noted, the variants occurred heterozygously

a performed by (Collin et al. 2010)

${ }^{\mathrm{b}}$ performed by (Sergouniotis et al. 2010)

- located in a highly polymorphic region with 2 known SNPs in the same region rs72183347 and rs72122505

- n.d. not done

- $\quad$ n.a. not applicable 
Interestingly, another prevalence study from a cohort with 286 affected individuals with Leber Congenital Amaurosis and arRP identified a large number of variants in C2orf71, however for none of the variants pathogenicity could be proven (Sergouniotis et al. 2010).

Although our study documents that $C 2 \operatorname{orf} 71$ is not a major gene for arRP, however at least for the French arRP population it is still an important gene to screen and its prevalence is similar to most of the other genes reported in arRP (Hartong et al. 2006).

\section{REFERENCES}

Abd El-Aziz MM, Barragan I, O'Driscoll CA, Goodstadt L, Prigmore E, Borrego S, Mena M, Pieras JI, El-Ashry MF, Safieh LA, Shah A, Cheetham ME, Carter NP, Chakarova C, Ponting CP, Bhattacharya SS, Antinolo G. 2008. EYS, encoding an ortholog of Drosophila spacemaker, is mutated in autosomal recessive retinitis pigmentosa. Nat Genet 40(11):1285-7.

Adzhubei IA, Schmidt S, Peshkin L, Ramensky VE, Gerasimova A, Bork P, Kondrashov AS, Sunyaev SR. 2010. A method and server for predicting damaging missense mutations. Nat Methods 7(4):248-9.

Audo I, Sahel JA, Mohand-Said S, Lancelot ME, Antonio A, Moskova-Doumanova V, Nandrot EF, Doumanov J, Barragan I, Antinolo G, Bhattacharya SS, Zeitz C. 2010. EYS is a major gene for rod-cone dystrophies in France. Hum Mutat 31(5):E1406-35.

Bandah-Rozenfeld D, Littink KW, Ben-Yosef T, Strom TM, Chowers I, Collin RW, den Hollander AI, van den Born LI, Zonneveld MN, Merin S, Banin E, Cremers FP, Sharon D. 2010a. Novel null mutations in the EYS gene are a frequent cause of autosomal recessive retinitis pigmentosa in the Israeli population. Invest Ophthalmol Vis Sci 51(9):4387-94.

Bandah-Rozenfeld D, Mizrahi-Meissonnier L, Farhy C, Obolensky A, Chowers I, Pe'er J, Merin S, Ben-Yosef T, Ashery-Padan R, Banin E, Sharon D. 2010b. Homozygosity mapping reveals null mutations in FAM161A as a cause of autosomal-recessive retinitis pigmentosa. Am J Hum Genet 87(3):382-91.

Barragan I, Borrego S, Pieras JI, Gonzalez-del Pozo M, Santoyo J, Ayuso C, Baiget M, Millan JM, Mena M, ElAziz MM, Audo I, Zeitz C, Littink KW, Dopazo J, Bhattacharya SS, Antinolo G. 2010. Mutation spectrum of EYS in Spanish patients with autosomal recessive retinitis pigmentosa. Hum Mutat 31(11):E1772-800.

Bernal S, Ayuso C, Antinolo G, Gimenez A, Borrego S, Trujillo MJ, Marcos I, Calaf M, Del Rio E, Baiget M. 2003. Mutations in USH2A in Spanish patients with autosomal recessive retinitis pigmentosa: high prevalence and phenotypic variation. J Med Genet 40(1):e8.

Carpineto P, Nubile M, Toto L, Aharrh Gnama A, Marcucci L, Mastropasqua L, Ciancaglini M. 2010. Correlation in foveal thickness measurements between spectral-domain and time-domain optical coherence tomography in normal individuals. Eye (Lond) 24(2):251-8.

Collin RW, Safieh C, Littink KW, Shalev SA, Garzozi HJ, Rizel L, Abbasi AH, Cremers FP, den Hollander AI, Klevering BJ, Ben-Yosef T. 2010. Mutations in C2ORF71 cause autosomal-recessive retinitis pigmentosa. Am J Hum Genet 86(5):783-8.

Hartong DT, Berson EL, Dryja TP. 2006. Retinitis pigmentosa. Lancet 368(9549):1795-809.

Langmann T, Di Gioia SA, Rau I, Stohr H, Maksimovic NS, Corbo JC, Renner AB, Zrenner E, Kumaramanickavel G, Karlstetter M, Arsenijevic Y, Weber BH, Gal A, Rivolta C. 2010. Nonsense mutations in FAM161A cause RP28-associated recessive retinitis pigmentosa. Am J Hum Genet 87(3):376-81.

Received <date>; accepted revised manuscript $<$ date $>$.

(C) 2010 WILEY-LISS, INC. 
Littink KW, van den Born LI, Koenekoop RK, Collin RW, Zonneveld MN, Blokland EA, Khan H, Theelen T, Hoyng CB, Cremers FP, den Hollander AI, Klevering BJ. 2010. Mutations in the EYS gene account for approximately $5 \%$ of autosomal recessive retinitis pigmentosa and cause a fairly homogeneous phenotype. Ophthalmology 117(10):2026-33, 2033 e1-7.

McGee TL, Seyedahmadi BJ, Sweeney MO, Dryja TP, Berson EL. 2010. Novel mutations in the long isoform of the USH2A gene in patients with Usher syndrome type II or non-syndromic retinitis pigmentosa. J Med Genet 47(7):499-506.

Ng PC, Henikoff S. 2001. Predicting deleterious amino acid substitutions. Genome Res 11(5):863-74.

Nishimura DY, Baye LM, Perveen R, Searby CC, Avila-Fernandez A, Pereiro I, Ayuso C, Valverde D, Bishop PN, Manson FD, Urquhart J, Stone EM, Slusarski DC, Black GC, Sheffield VC. 2010. Discovery and functional analysis of a retinitis pigmentosa gene, C2ORF71. Am J Hum Genet 86(5):686-95.

Ramensky V, Bork P, Sunyaev S. 2002. Human non-synonymous SNPs: server and survey. Nucleic Acids Res 30(17):3894-900.

Rivolta C, Sweklo EA, Berson EL, Dryja TP. 2000. Missense mutation in the USH2A gene: association with recessive retinitis pigmentosa without hearing loss. Am J Hum Genet 66(6):1975-8.

Sergouniotis PI, Li Z, Mackay DS, Wright GA, Dev Borman A, Devery SR, Moore AT, Webster AR. 2010. A survey of DNA variation of C2ORF71 in probands with progressive autosomal recessive retinal degeneration and controls. Invest Ophthalmol Vis Sci [Epub ahead of print].

\section{SUPPORTING FILES:}

Supplementary Figure 1:

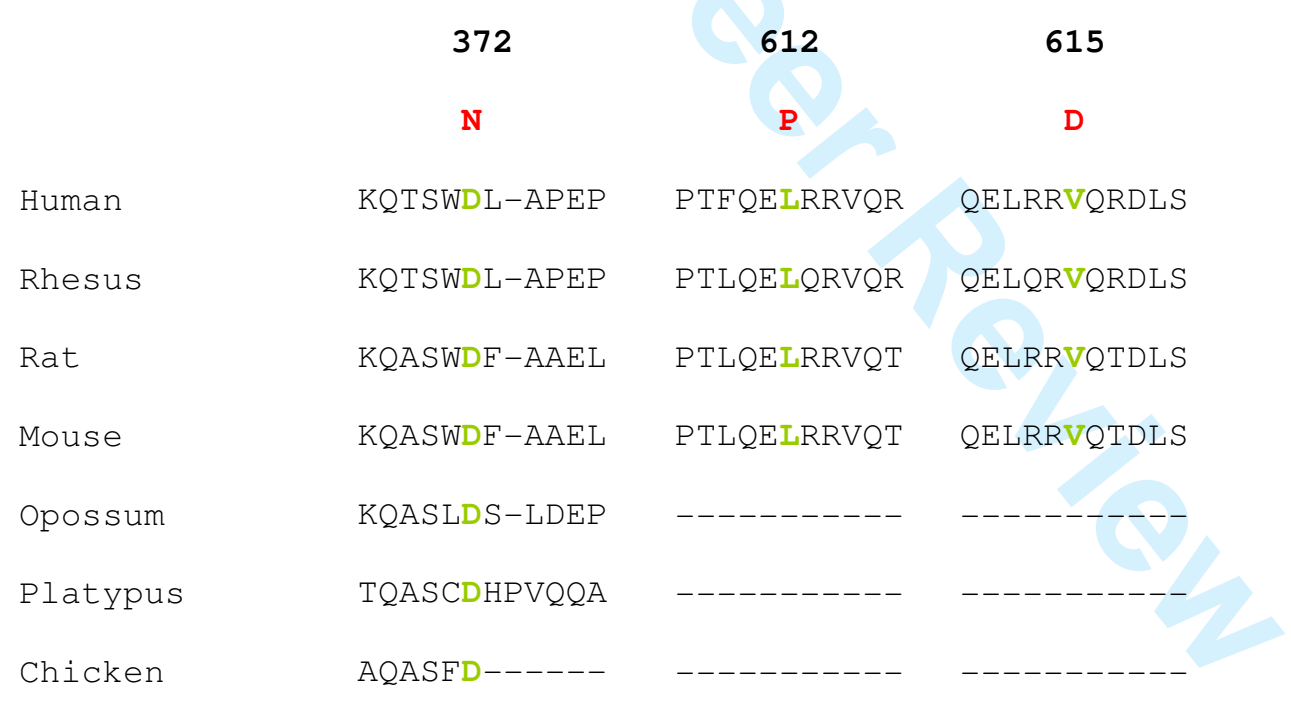

Evolutionary conservation of altered amino acid residues (red) in other orthologs. Multiple amino acid alignments show evolutionary conservation of mutated residues (green). 


\section{$12<$ First Author et al.>}

Supplementary Table 1: primer sequences used for C2ORF71 PCR amplification and sequencing

\begin{tabular}{cc}
\hline Primer & Sequence (5'-3') \\
\hline C2ORF71 1A F & CAACAGGACGACAGGTACCA \\
C2ORF71 1A R & GAAGCAGGATCTCCCATGAG \\
C2ORF71 1B F & CAATTCGGCCAGGATGTCAG \\
C2ORF71 1B R & GTGTAGATAGGTGTAAGCCTG \\
C2ORF71 1C F & GTCACACGTCAAGCACACAG \\
C2ORF71 1C R & GCTTATTTTCCAAGTGGGTTGC \\
C2ORF71 1D F & CAGGTGCTCAATGGCACAGT \\
C2ORF71 1D R & GAGATGAAGCGTCCATCGGC \\
C2ORF71 2 F & GTTGCTTTGTTCAGAGCAGCA \\
C2ORF71 1E F & GTACAAGCCCAGAAAATATCAC \\
C2ORF71 1J F & CACCACAAAGCGGCGAACTT \\
C2ORF71 1E R & GTGACTCTGGAGACACGACT \\
C2ORF71 1I R & GAAGATCTTTTGGCCCATTCG \\
C2ORF71 1F F & CGAAAGGATCAAGTTTGTCCC \\
\hline & \\
C2ORF71 1F R & CTCTCCGTGGGACTGAAAGT
\end{tabular}

John Wiley \& Sons, Inc. 


\begin{tabular}{|c|c|c|c|c|c|}
\hline Exon & Sequence variation & Consequence & $\begin{array}{c}\text { Frequency in patient } \\
\text { chromosomes }\end{array}$ & $\begin{array}{l}\text { Frequency in control } \\
\text { chromosomes }\end{array}$ & SNP ID \\
\hline 1 & c. $37 \mathrm{~A}>\mathrm{T}$ & pSer13Cys & $\begin{array}{l}15 / 418 \\
{ }^{\mathrm{b}} 1 / 572\end{array}$ & $\begin{array}{c}\text { n.d. } \\
{ }^{\mathrm{b}} 0 / 364\end{array}$ & rs10084168 \\
\hline 1 & c. $60 \mathrm{G}>\mathrm{A}$ & p.Gln20Gln & $\begin{array}{l}120 / 418 \\
{ }^{b} 101 / 572\end{array}$ & $\begin{array}{c}\text { n.d } \\
{ }^{\mathrm{b}} 82 / 364\end{array}$ & rs 35929540 \\
\hline 1 & c. $258 \mathrm{G}>\mathrm{A}$ & p.Arg86Arg & $\begin{array}{l}120 / 418 \\
{ }^{b} 111 / 572\end{array}$ & $\begin{array}{c}\text { n.d. } \\
{ }^{\mathrm{b}} 77 / 364\end{array}$ & rs62132765 \\
\hline 1 & c. $366 \mathrm{C}>\mathrm{T}$ & p.His122His & $1 / 418$ & n.d. & rs 17007546 \\
\hline 1 & c. $740 \mathrm{~T}>\mathrm{T}$ & p.Val247Ala & $1 / 418$ & $0 / 190$ & rs 77828062 \\
\hline 1 & c. $755 \mathrm{C}>\mathrm{A}$ & p.Ala252Asp & $10 / 418$ & $1 / 190$ & SNP2-29149877 \\
\hline 1 & c. $1262 \mathrm{~A}>\mathrm{G}$ & p.Lys421Arg & $\begin{array}{l}12 / 418 \\
{ }^{\mathrm{b}} 0 / 572\end{array}$ & $\begin{array}{l}\text { n.d. } \\
{ }^{\mathrm{b}} 3 / 190\end{array}$ & rs 17007544 \\
\hline 1 & c. $1452 \mathrm{C}>\mathrm{T}$ & p.Ser484Ser & $\begin{array}{l}151 / 418 \\
{ }^{b} 153 / 572\end{array}$ & $\begin{array}{c}\text { n.d. } \\
{ }^{\mathrm{b}} 81 / 190\end{array}$ & rs13385188 \\
\hline 1 & c. $1739 \mathrm{C}>\mathrm{T}$ & p.Thr580Met & $\begin{array}{l}33 / 418 \\
{ }^{\mathrm{b}} 0 / 572\end{array}$ & $\begin{array}{l}\text { n.d. } \\
{ }^{\mathrm{b}} 5 / 190\end{array}$ & rs10166913 \\
\hline
\end{tabular}

HUMAN MUTATION Mutation in Brief \#__ (20XX) Online

\section{MUTATION IN BRIEF}

\section{HUMAN MUTATION}

Supplementary Table 2: C2orf71 known non-disease causing variants in our cohort of 209 arRP patients with their respective frequency 
$14<$ First Author et al.>

\begin{tabular}{|c|c|c|c|c|c|}
\hline 1 & c. $1942 \mathrm{G}>\mathrm{C}$ & p.Ala648Pro & $\begin{array}{l}4 / 418 \\
\text { b } 1 / 572\end{array}$ & $\begin{array}{c}\text { n.d. } \\
{ }^{\mathrm{b}} 1 / 190\end{array}$ & rs75276619 \\
\hline 1 & c. $2112 \mathrm{~T}>\mathrm{C}$ & p.Asn704Asn & $\begin{array}{l}153 / 418 \\
{ }^{\mathrm{b}} 168 / 572\end{array}$ & $\begin{array}{c}\text { n.d. } \\
{ }^{b} 123 / 380\end{array}$ & rs 10200693 \\
\hline 1 & c. $2374 \mathrm{C}>\mathrm{G}$ & p.Leu792Val & $\begin{array}{l}120 / 418 \\
{ }^{b} 103 / 572\end{array}$ & $\begin{array}{c}\text { n.d. } \\
{ }^{\mathrm{b}} 66 / 380\end{array}$ & rs17744093 \\
\hline 1 & c. $2499 \mathrm{G}>\mathrm{A}$ & p.Pro833Pro & $\begin{array}{l}121 / 418 \\
{ }^{b} 106 / 572\end{array}$ & $\begin{array}{c}\text { n.d. } \\
{ }^{\mathrm{b}} 70 / 380\end{array}$ & rs34253433 \\
\hline 1 & c.3264_3266del & p.Pro1089del & $11 / 418$ & n.d. & rs75460934 \\
\hline 2 & c. $3761 \mathrm{C}>\mathrm{T}$ & p.Pro1254Leu & $1 / 418$ & $0 / 190$ & rs1975713 \\
\hline
\end{tabular}

berformed by (Sergouniotis et al. 2010) 